\title{
Effects of Fish Protein Concentrate and Lipids Derived from the Muscle of Stromateid Fish, Cubiceps gracilis on Growth and Liver Lipids in Rats
}

\author{
Kinji TAKADA ${ }^{* 1}$ and Hisao KAMTYA ${ }^{* 2}$ \\ (Received November 28, 1980)
}

\begin{abstract}
Fish protein concentrate (FPC) and lipids were prepared from the muscle of the stromateid fish, Cubiceps gracilis, to investigate their nutritive effects on rats. The FPC was found to rather promote the growth of rats with the protein efficiency ratio 3.84 , which is higher than that of casein, 3.26. The muscle lipid represented mainly by diacyl glyceryl ethers (DAGE's) showed a nutritional value comparable to that of cottonseed oil. The rats fed with a DAGE diet accumulated in their liver lipid detectable amounts of DAGE's which were similar in composition to those of the muscle lipid of C. gracilis.
\end{abstract}

Recent fishing efforts toward deep sea have led to a discovery of a variety of fish species which possess wax esters or diacyl glyceryl ethers (DAGE's) as the major lipids ${ }^{1,2)}$. Since ingestion of wax esters in quantity causes severe diarrhea and seborrhea in humans some of the wax esterrich fish have been prohibited from selling as food. The safety of DAGE's as food has not yet been confirmed, but it may be possible to use these fish as the raw materials for fish protein concentrate (FPC) because their DAGE content could be reduced by solvent extraction during the preparation process.

In our studies DAGE's and FPC were prepared from the stromateid fish, Cubiceps gracilis, and fed to rats to observe their effects on growth and liver lipids of the animals.

\section{Materials and Methods}

\section{Materials}

Specimen of $C$. gracilis were caught by a midwater trawler of Nihon Suisan Co., Ltd., off New Zealand and kept frozen until used for extraction.

\section{Preparation of FPC}

FPC was prepared by the method of PoweR ${ }^{3)}$. A $500 \mathrm{~g}$ portion of the minced muscle was extracted with $1.5 \mathrm{l}$ of hot 2-propanol below $80^{\circ} \mathrm{C}$ for $1 \mathrm{~h}$.
The mixture was centrifuged and the residue was extracted twice as above. The residue thus obtained was dried in vacuo at room temperature and powdered by a crusher.

\section{Analysis of $F P C$}

Determination of moisture, ash, lipid, and protein in FPC was carried out by the A.O.A.C. method ${ }^{4}$. Amino acids were determined by a Hitachi amino acid analyzer KLA-5 after hydrolysis in $6 \mathrm{~N} \mathrm{HCl}$ at $110^{\circ} \mathrm{C}$ for $24 \mathrm{~h}$.

\section{Characterization of the Lipids in 2-Propanol Extract}

The 2-propanol extract was partitioned between diethyl ether and water. The ether layer was analyzed for lipid by the method reported previously ${ }^{3,3)}$. The lipid extracted from the FPC by the A.O.A.C. method" was analyzed in the same manner. The lipid recovered from 2-propanol extract was used as DAGE's in feeding experiments.

\section{Feeding Test}

Male rats of the Wister strain weighing 63.0 $76.5 \mathrm{~g}$ were kept on control diet (Table 1) for one week before feeding test. Five rats in each group were fed with 4 different diets (Table 1) for 4 weeks. They were kept in an air-conditioned room at $23^{\circ} \mathrm{C}$ and with $60 \%$ relative humidity during experiment.

Body weight of each rat was recorded everyday

*I Central Research Laboratory of Kantoishi Pharmaceutical Co., Ltd., Tokorozawa, Saitama 359 (1)

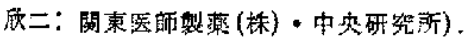

*2 Laboratory of Marine Biochemistry, Faculty of Agriculture, The University of Tokyo, Bunkyo-ku, Tokyo 113 (神谷久男: 果京大学農学部). Present address: Kitasato University School of Fisheries Sciences, Sanriku, Iwate 022-01 (現在：北里 大学水産学部)。 
Table 1. Composition of diets

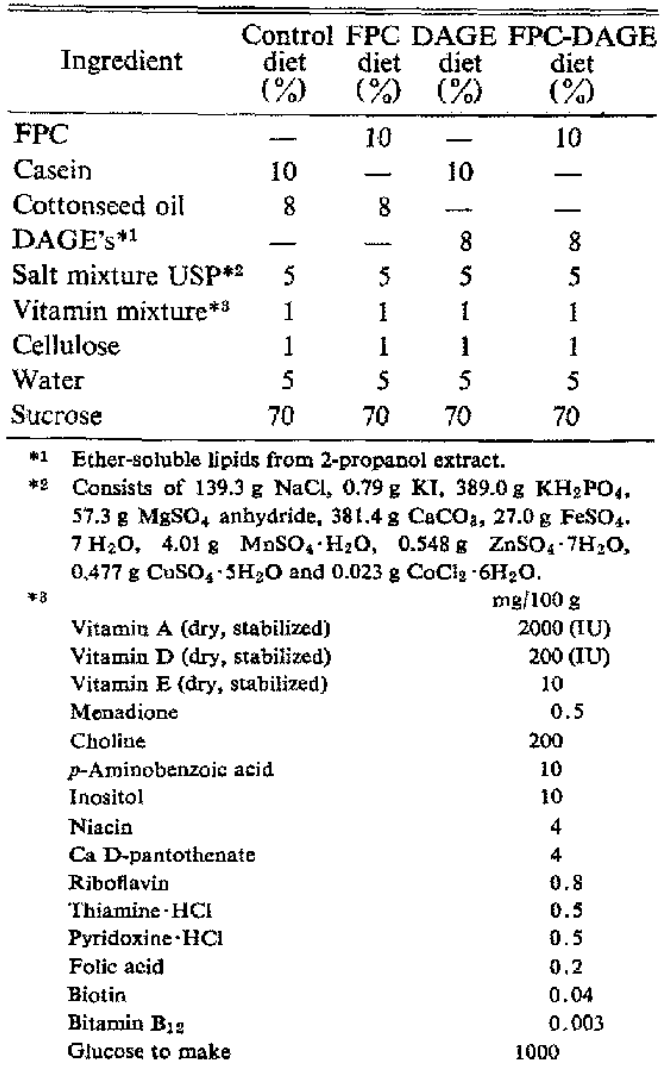

during a period of 4 weeks. Protein efficiency ratios (PER) were calculated according to the method of A.O.A.C. ${ }^{7 \text {. }}$.

\section{Analysis of Lipid Composition of the Rat Liver}

On the last day of feeding test the rats were sacrificed, and the pooled liver specimen from each group was analyzed for lipid composition by a Florisil column chromatographic method or by TLC as reported previousil ${ }^{5,8)}$.

\section{Results and Discussion}

\section{Recovery and Properties of FPC}

The recovery of FPC amounted to $20 \%$ of the total fish muscle. C. gracilis FPC contained $82.3 \%$ of protein and $5.1 \%$ of moisture; these values resemble those of FPC's prepared from usual fish ${ }^{3)}$. Its lipid and ash contents scored $10.7 \%$ and $5.8 \%$ respectively. Although $19.0 \%$ of the lipids in raw material was excluded during preparation of FPC, the lipid content was still high as compared to FPC products from other fish species ${ }^{5)}$. Amino acid composition of $C$. gracilis FPC (Table 2) indicates that it contains basic amino acids 1.5-2.5 times as much as those in usual fish muscle $e^{9-11}$. It should be noted that the content of histidine is 4 times higher than that in FPC's from herring, hadock or anchovil' ${ }^{12}$.

Table 2. Amino acid composition of FPC prepared from the stromateid fish

\begin{tabular}{lr}
\hline Amino acids & Content (g/100 g protein) \\
\hline Glycine & 6.29 \\
Alanine & 7.90 \\
Valine & 7.68 \\
Leucine & 10.21 \\
Isoleucine & 3.96 \\
Serine & 4.98 \\
Threonine & 5.50 \\
Methionine & 1.26 \\
Aspartic acid & 11.15 \\
Glutamic acid & 17.34 \\
Tyrosine & 3.96 \\
Phenylalanine & 5.22 \\
Proline & 4.06 \\
Tryptophan* & 2.47 \\
Arginine & 9.73 \\
Lysine & 13.85 \\
Histidine & 10.75 \\
\hline Determined by the method of Goonwry and MorToN
\end{tabular}

Lipid Composition of FPC and of the Fat Soluble Fraction of 2-Propanol Extract

As shown in Table 3, C. gracilis FPC contained $10.7 \%$ of lipids; the content of lipids in 2-propanol extract was $19.0 \%$. Both lipids possess properties similar to each other (Table 3).

Table 3 Properties of lipids in FPC and the 2propanol extract of the stromateid fish

\begin{tabular}{|c|c|c|}
\hline Components & $\begin{array}{l}\text { FPC } \\
(\%)\end{array}$ & $\underset{(\%)}{\text { DAGE's* }}$ \\
\hline Lipid content & 10.7 & 19.4 \\
\hline $\begin{array}{l}\text { Unsaponificables content } \\
\text { in lipid }\end{array}$ & 24.8 & 26.4 \\
\hline In $\left\{\begin{array}{l}\text { Hydrocarbons } \\
\text { Sterols } \\
\text { GE's } \\
\text { Unknown }\end{array}\right.$ & $\begin{array}{r}0.7 \\
1.2 \\
83.7 \\
5.9\end{array}$ & $\begin{array}{r}0.4 \\
2.7 \\
86.9 \\
3.1\end{array}$ \\
\hline
\end{tabular}

* Ether-soluble lipids from 2-propanol extract.

\section{Growth of Rats}

The weight gain, food intake, and protein efficiency ratio are seen in Table 4. Rats in each group showed normal appetite during feeding experiment and no abnormal signs in appearanse and in internal organs except for one rat in DAGE 
Table 4. Body weight and protein efficiency ratio (PER)

\begin{tabular}{|c|c|c|c|c|c|}
\hline Group & $\begin{array}{c}\text { Initial body } \\
\text { weight } \\
\text { (g) }\end{array}$ & $\begin{array}{c}\text { Weight } \\
\text { gain } \\
\text { (g) }\end{array}$ & $\begin{array}{c}\text { Food } \\
\text { intake } \\
(g)\end{array}$ & $\begin{array}{c}\text { Protein } \\
\text { intake } \\
\text { (g) }\end{array}$ & PER \\
\hline \multirow{5}{*}{ Control } & 63.0 & 88.0 & 312.9 & 28.2 & 3.13 \\
\hline & 67.5 & 95.5 & 308.9 & 27.8 & 3.44 \\
\hline & 68.0 & 96.0 & 297.9 & 26.8 & 3.58 \\
\hline & 68.5 & 83.0 & 306.3 & 27.5 & 3.01 \\
\hline & 75.5 & 88.5 & 315.3 & 28.4 & 3.12 \\
\hline \multirow[t]{3}{*}{ Mean } & 68.5 & 90.2 & 308.3 & 27.7 & 3.26 \\
\hline & 65.0 & 93.5 & 307.1 & 25.3 & 3.77 \\
\hline & 69.0 & 105.0 & 314.5 & 25.9 & 4.06 \\
\hline \multirow[t]{3}{*}{ FPC } & 64.0 & 93.5 & 305.9 & 25.2 & 3.71 \\
\hline & 72.0 & 99.5 & 305.3 & 25.1 & 3.96 \\
\hline & 74.0 & 96.5 & 315.8 & 26.0 & 3.71 \\
\hline \multirow[t]{3}{*}{ Mean } & 68.8 & 97.6 & 309.7 & 25.5 & 3.84 \\
\hline & 71.5 & 92.5 & 315.1 & 25.9 & 3.57 \\
\hline & 65.0 & 85.5 & 275.4 & 22.7 & 3.77 \\
\hline \multirow[t]{3}{*}{ FPC-DAGE } & 66.5 & 84.0 & 286.2 & 23.6 & 3.57 \\
\hline & 67.0 & 86.5 & 303.5 & 25.0 & 3.46 \\
\hline & 76.5 & 84.5 & 302,0 & 24.9 & 3.40 \\
\hline \multirow[t]{3}{*}{ Mean } & 69.3 & 86.6 & 296.4 & 24.4 & 3.55 \\
\hline & 68.0 & 87.0 & 308.6 & 30.2 & 2.88 \\
\hline & 68.5 & 88.5 & 303.6 & 29.7 & 2.98 \\
\hline \multirow[t]{3}{*}{ DAGE } & 70.5 & 86.5 & 301.8 & 29.5 & 2.93 \\
\hline & 70.5 & 80.0 & 308.6 & 30.2 & 2.65 \\
\hline & 75.0 & 94.0 & 317.8 & 31.1 & 3.03 \\
\hline Mean & 70.5 & 87.2 & 308.1 & 30.1 & 2.89 \\
\hline
\end{tabular}

diet group that lost its hairs in the hind limb but recovered by the $23 \mathrm{rd}$ day. Rats in FPC and FPC-DAGE diet groups gave PER's of 3.84 and 3.55 , respectively, which are greater than that of control group, 3.26. This suggests that $C$. gracilis FPC is superior to casein as a protein source. In contrast to the control group, a casein diet containing DAGE gave a lower PER of 2,89 . It is not clear whether this is due to the depression of growth of rats by DAGE's.

Ackman et al. ${ }^{39)}$ obtained a similar result in feeding experiment of FPC prepared from the white barracudina, Paralepis rissoi Kroyeri; 2.81 for PER of FPC and 2.50 for that of casein. On the contrary, KINUMAKI et al. ${ }^{14}$ found that fish meal prepared from the flesh of Centrolophus niger, one of the stromateid fish, showed a PER as low as 0.78. KINUMAKI et al. ${ }^{14}$ reported that no difference occurred in growth of rats fed with either soybean oil or lipids obtained from the $C$. niger muscle by hot benzene extraction. However, KANEDA et al. ${ }^{(5)}$ observed that DAGE's obtained by molecular distillation from liver oils of the shark, Chimaera barbouri, were well below soybean oil in nutritive value for rats, though less hazardous to test animals than wax esters.

\section{Liver Lipids}

The rats in both DAGE and FPC-DAGE groups were found to contain more lipids in the liver than the control group, as shown in Table 5.

Table 5. Liver lipids of rats fed with 4 diets*

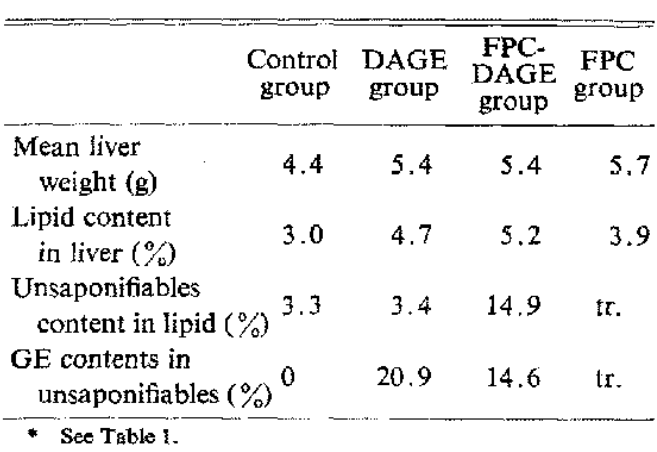

From these results, it is apparent that rats accumulate lipids in the liver from diet; more lipids are accumulated from higher lipid containing-diet. This is also true for DAGE's. A great quantity 

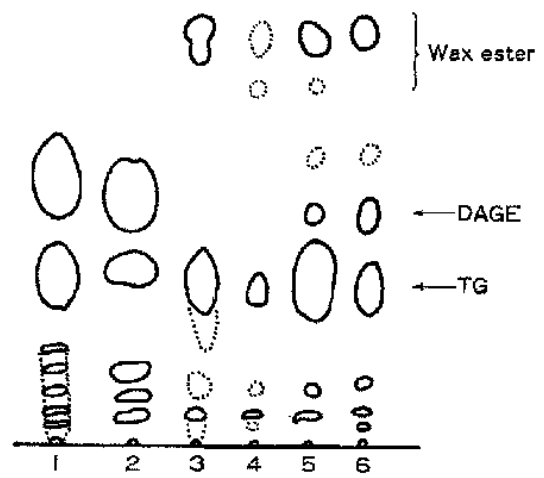

Fig. 1. Thin layer chromatograms of lipids obtained from FPC and rat liver, and 2-propanol extract from stromateid muscle.

1: Acetone soluble lipids in FPC.

2: 2-Propanol extract from stromateid muscle.

3: Acetone soluble liver lipids of control diet group.

4: Acetone soluble liver lipids of FPC diet group.

5: Acetone soluble liver lipids of DAGE diet group.

6: Acetone soluble liver lipids of FPC-DAGE diet group.

of glyceryl ethers (GE's) ranging from 15 to $20 \%$ of unsaponifiables were accumulated in the liver of rats fed with the diet containing DAGE's. On the other hand, only a trace of DAGE's was detected in the liver of FPC group by Florisil column chromatography, although FPC contained considerable amounts of DAGE's. No DAGE was detected in the liver of the control group by TLC (Fig. 1). The GE composition of liver lipids from DAGE and FPC-DAGE groups showed a similarity to each other (Table 6). Liver lipids exhibited GE composition resembling those of lipids from FPC and 2-propanol extract except for $C_{18 \text { :0 }}$ that was contained in smaller percentages. This indicates that $\mathrm{C}_{16: 0}$ component may be metabolized more rapidly than other components in the rat liver.

It comes to a conclusion that fish such as $C$. gracilis having DAGE's as the major lipids in the muscle may be acceptable as a material for FPC. However, further examination on their toxicity is required since $\operatorname{IIDA}^{13}$ reported that the muscle of Stromateus maculatus with a large quantity of DAGE's might cause diarrhea in humans.

\section{Acknowledgements}

The authors wish to express their sincere thanks
Table 6. Giyceryl ether compositions of the lipids of FPC (A), the 2-propanol soluble lipids from stromateid muscle (B), and the acetone soluble lipids from livers of rat fed with two different diets (C)

\begin{tabular}{|c|c|c|c|c|}
\hline \multirow[b]{2}{*}{$\mathrm{GE}^{*}$} & \multirow[b]{2}{*}{$\mathbf{A}$} & \multirow[b]{2}{*}{ B } & \multicolumn{2}{|c|}{$C$} \\
\hline & & & $\begin{array}{l}\text { DAGE diet } \\
\text { group }\end{array}$ & $\begin{array}{l}\text { FPC-DAGE } \\
\text { diet group }\end{array}$ \\
\hline $12: 0 \mathrm{br}$ & - & - & 0.3 & 1.3 \\
\hline $13: 0 \mathrm{br}$ & - & - & 0.2 & 2.1 \\
\hline $13: 1$ & - & - & 0.1 & tr. \\
\hline $14: 0 \mathrm{br}$ & - & - & 0.2 & 2.6 \\
\hline $14: 0$ & 3.3 & 4.8 & - & - \\
\hline $14: 1$ & 0.1 & 0.4 & 0.6 & 0.6 \\
\hline $15: 0 \mathrm{br}$ & 0.1 & 0.1 & 1.3 & tr. \\
\hline $15: 0$ & 1.6 & 1.7 & 1.0 & 3.6 \\
\hline $15: 1$ & - & - & - & 0.5 \\
\hline $16: 0 \mathrm{br}$ & 0.4 & 0.1 & 0.7 & 0.4 \\
\hline $16: 0$ & 34.9 & 33.5 & 24.8 & 20.3 \\
\hline $16: 1$ & 3.8 & 7.4 & 2.4 & 1.8 \\
\hline $17: 0$ br & 1.2 & 1.3 & 0.7 & 1.6 \\
\hline $17: 0$ & 1.0 & 2.3 & - & 4.9 \\
\hline $17: 1$ & 1.2 & 1.5 & - & - \\
\hline $18: 0 \mathrm{br}$ & 1.7 & 0.7 & 1.2 & 1.5 \\
\hline $18: 0$ & 2.6 & 3.3 & 6.4 & 9.6 \\
\hline $18: 1$ & 44.6 & 41.1 & 54.9 & 38.8 \\
\hline $18: 2$ & 1.0 & - & - & - \\
\hline $19: 0$ & - & - & - & 3.0 \\
\hline $19: 1$ & 0.6 & - & - & - \\
\hline $20: 0 \mathrm{br}$ & - & - & 5.0 & - \\
\hline $20: 1$ & 2.0 & 0.3 & - & 6.8 \\
\hline $21: 0$ & - & 1.3 & - & - \\
\hline
\end{tabular}

* Indicated by carbon cbain length and double bond of the alkyl moiety.

to Professor M. Mon, Toyoko Women's College for his kind supply of C. gracilis and for his advice during the present study. Thanks will aoso go to Dr. T. KInUMAKX and Miss K. Arat, Tokai Regional Fisheries Research Laboratory for their kind cooperation in the feeding experiment. This study was supported partly by a grant from the Ministry of Education.

\section{References}

1) H. IIDA: Bull. Japan. Soe. Sci. Fish., 37, 338 (1971).

2) M. KaYAMA: Kagaku to Seibutsu, 9, 368-370 (1971).

3) H. E. POWer: J. Fish. Res. Board Can, 19, 1039-1045 (1962).

4) W. HoRwitz: Official Methods of Analysis of the Association of Official Analytical Chemists, 11 th ed., A.O.A.C., Washington, D.C., 1970, pp. 296-297. 
5) M. MoRI, S. HikichI, H. KaMrYA, and Y. HaSHIмото: Bufl. Japan. Soc. Sci. Fish, 38, 56-63 (1972).

6) K. TAKADA, H. KamMY, and the late Y. HASHIMoro: Bull. Japan. Soc. Sci. Fish., 45, 605-610 (1979).

7) W. HoRwrTz; Official Methods of Analysis of the Association of Official Analytical Chemists: 11 th ed., A.O.A.C., Washington, D.C., 1970, p. 800 .

8) G. D. Kapsionis: in "Production of Fish-Protein Concentrate" (ed. by United Nations), Part II, United Nations, New York, 1972, pp. 31-40.

9) S. Konosu, S. Katori, R. Ota, S. Eguchr, and T. MoR: Bull. Japan. Soc. Sci. Fish., 21, 11631166 (1956).

10) F. Matsutura, S. Konosu, R. Ota, S. Katori, and K. Tanaka: Bull. Japan. Soc. Sci. Fish., 20, 941-945 (1955).
11) S. Konosu and F. MAtsuURa: Bull. Japan. Soc. Sci. Fish., 26, 1040-1049 (1960).

12) C.O.Chichester, F.MONCKeserg, and E.YANez: in "Production of Fish-Protein Concentrate" (ed. by United Nations) Part II, United Nations, New York, 1972, pp. 12-29.

13) R. G. ACKMAN, C. A. EAtoN, and P.J. KE: in "Technical Conference on Fishery Products" (ed. by FAO), FII: FP/73/E-21, FAO of The United Nations, Rome, 1973, pp. 1 13 .

14) T. Kinumak.l, K. Aral, K. Sugr, and S. Isekr: Bull. Tokai Reg. Fish. Res. Lab., No. 91, 73-91 (1971).

15) S. KANEDA, K. IshIr, S. SAKAI, and K. ARAI: Bull. Tokai Reg. Fish, Res, Lab., No. 12, 1-44 (19S5).

16) T. W. Goodwin and R. A. Morton: Biochem. $J ., 40,628-632$ (1946). 